\title{
The Impact of Foreign Direct Investment on Economic Growth in Sri Lanka
}

\author{
A.M.M. Mustafa \\ Department of Management \\ South Eastern University of Sri Lanka \\ E-mail: amustafa@seu.ac.lk \\ Dr. S.Santhirasegaram \\ Department of Economics \\ Faculty of Arts \\ University of Jaffna \\ E-mail:selvarathnams@hotmail.com
}

\begin{abstract}
Foreign Direct Investment (FDI) has been used by developing countries as a tool to solve their economic problems in the recent past. Sri Lanka is also not an exception to this practice. This research is aimed at tracing the impact of FDI in promoting economic growth by using the time series annual data from 1978 - 2012 in Sri Lanka. Multiple regression models were used to estimate the impact of FDI on economic growth. The Minitab, SAS, Excel and E-views software were used for data analysis. The empirical evidence shows that FDI positively and statistically influences to determine economic growth in Sri Lanka. However, this study further reveals that the actual impact of FDI can be felt after time lag of two years.
\end{abstract}

Keywords: Economic Growth, FDI

\section{Introduction}

Foreign Direct Investment (FDI) has been one of the defining features of the World economy over the past thirty five years. Firms in all industries are expanding their operations through FDI than ever before in both developed and developing countries. FDI is considered as one of the important economic force through which developing countries can carry out economic growth consequently. In this backdrop, Sri Lanka is also inviting FDI itself for the reason that FDI plays a major role in contributing to the local resource base available for the investment to obtain sufficient rates of economic growth, which will improve standard of living of the people. In this regards, Sri Lanka offers attractive investment opportunities for foreign companies and has adopted a number of policies to attract foreign direct investment into the country. Hence, Sri Lanka revised its policy extensively in 1977 from extreme controls to the far reaching liberalization. The objective of the reform was to attract FDI into the country. As a result, Sri Lanka received Rs.24 Millions of FDI in 1978, whereas it received Rs.49, 008 Millions of FDI in 2010 (Economics and Social Statistics of Sri Lanka, 2011).

Foreign Direct Investment (FDI) is defined as foreign investors moving their assets into another country where they have control over the management of assets and profits (Graham $\&$ Spaulding, 2005). The role of FDI has been 
widely recognized as a growth-enhancing factor in developing countries. FDI helps host countries to achieve investment levels beyond their own domestic saving in various ways. More importantly, FDI is an important means of transferring modern technology and innovation from developed to developing countries. However, there is convincing evidence that the growth enhancing effect from FDI seems to vary from country to country. FDI can even adversely affect the growth process for some countries (Balasubramanyam et al., 1996, Borensztein et. al., 1998, World Investment Report 1999 and Hasan, 2001).

In developing countries, FDI helps to tackle socio-economic problems such as unemployment, deficit balance of payment, lack of capacity, scarcity of foreign exchange, and poor technological ability, etc. Many analysts express the belief that the promotion of FDI inflow into developing economies is a key solution to resolve above socioeconomic problems faced by host countries like Sri Lanka (Ram et al, 2002). Further, there are many other advantages from FDI such as new technology, management, marketing management, global market prices, linkage with local economy, transfer of technical skills, relation with international market, capital formation, favorable balance of payment, infrastructure development, tourism development and resource utilization. These all components will enhance by inviting more FDI to the home country in order to achieve economic growth.

After the Independence of Sri Lanka, particularly after 1960, it continuously faced many such social and economical problems as lack of investment, unemployment, balance of payment and deficit budget. Even though Sri Lankan government had introduced many strategies to mitigate these problems, the solution could not be achieved for diminishing the problems in the country. The main reason for this issue is the contribution of Total Domestic Investment (TDI) was lower in the Gross Domestic Production (GDP). But, based on previous studies, it is understood that the FDI has contributed in the development of GDP for mitigating economic problems globally (Moudatsou, 2001). Therefore, this research tries to examine the contribution of FDI in the economic growth of Sri Lanka after liberalization policy reformation in 1977 perpetually.

\section{Literature Review}

Researches related to FDI have increased worldwide. Many studies have investigated the relationship between FDI and economic growth. Rodan (1961), Chenery and Strout (1966) in the early 1960s argued that foreign capital inflows had a favorable effect on the economic growth towards developing countries. It is explained that FDI can have a favorable short-term effect on growth as it expands the economic activity. However, in the long run it reduces the growth rate due to the dependence of the developing countries. The studies that used the endogenous growth theory challenged this view in explaining the long run growth rate of the economy by using endogenous variables. Chang and Zhang (1995) using the time series data for the period of 1979-93, estimates the regression between GNP, domestic saving in one period lag, and FDI in one period lag. The result of the study shows that there is a positive relationship between FDI and GNP and it is significant at 5 per cent level for the Chinese economy. Bashir (1999) examines the relationship between FDI and growth empirically in some MENA countries, using panel data, varying across regions and over time. Alam (2000) in his comparative study of FDI and economic for 
Indian and Bangladesh economy stresses that though the impact of FDI on growth is more in the case of Indian economy yet it is not satisfactory. Chakraborty and Basu (2002) try to find the short run dynamics of FDI and growth. The study reveals that GDP in India is not Granger caused by FDI; the causality runs more from GDP to FDI and trade liberation policy of the Indian government has some positive short run impact on the FDI flow.

The above reviewed research articles generate an argument whether FDI should be encouraged to the economic growth in developing countries. The present study is therefore an endeavor to examine the impact of FDI on Sri Lankan economic growth, by using time series data.

\section{Methodology}

The study covers the period 1978 - 2012 as time series data. Data relevant to this study was collected from the secondary sources such as International Financial Statistics (IFS), World Investment Reports 1990 - 2012, Investors Guide, Central Bank Annual Reports 1977 2012, and Economic and Social Statistics in Sri Lanka 1990 - 2012. Correlation method and Multiple Regression models were used. Ordinary Least Square (OLS) method is used to estimate the parameters of the model. E-views, Excel, and Minitab statistical software have used for the data analysis.

Multiple regression models such as Linear model, Log - Linear model, Log - Log model, and Lin - Log model have been used for data analysis. The model is selected based on adjusted $R^{2}$, the estimated $\mathrm{F}$ value, DurbinWatson ' $d$ ' statistics and Variance inflating factor (VIF).
The following production function is used for testing the contribution of FDI in GDP of Sri Lanka.

$$
Y=f(A, K, L)
$$

Where $y$ is output (Gross Domestic Production), $L$ is employment and $k$ is capital stock. According to the new (endogenous) growth theory, $A$ is endogenously determined by economic factors.

The relationship between FDI and GDP is developed by following function.

$$
G D P=f(F D I, D I, L F)
$$

Where, GDP is Gross Domestic Production, FDI is foreign direct investment, $D I$ is domestic investment and $L F$ is Labour Force.

\section{Model Selection}

Adjusted $R^{2}$, the estimated $\mathrm{F}$ value, DurbinWatson (DW) 'd' statistics and Variance inflating factor (VIF) for the model are presented in following table.

\section{Models - Gross Domestic Production}

\begin{tabular}{|l|c|c|c|c|c|}
\hline \multicolumn{1}{|c|}{ Models } & P & F & DW & VIF & $\begin{array}{c}\text { R-Sq } \\
\text { (adj) } \\
\text { \% }\end{array}$ \\
\hline $\begin{array}{l}R G D P_{t}=\beta_{0}+\beta_{1} R F D I_{t} \\
+\beta_{2} R D I_{t}+\beta_{3} L F_{t}+u_{t}\end{array}$ & $\mathbf{0 . 0 0 0 *}$ & $\mathbf{7 5 0 . 3 7 1}$ & $\mathbf{1 . 4 8}$ & $\begin{array}{l}\mathbf{5 . 3}- \\
\mathbf{1 0 . 8}\end{array}$ & $\mathbf{9 6 . 6 \%}$ \\
\hline $\begin{array}{l}R G D P_{t}=\beta_{0}+\beta_{1} \log R F D I_{t} \\
+\beta_{2} \log R D I_{t}+\beta_{3} \log L F_{t}+u_{t}\end{array}$ & $\mathbf{0 . 0 0 0 ^ { * }}$ & $\mathbf{2 8 6 . 7 0}$ & $\mathbf{1 . 7 2}$ & $\mathbf{3 . 2 - 9 . 6}$ & $\mathbf{9 6 . 5 \%}$ \\
\hline $\begin{array}{l}\log R G D P_{t}=\beta_{0}+\beta_{1} \log R F D I_{t} \\
+\beta_{2} \log R D I_{t}+\beta_{3} \log L F_{t}+u_{t}\end{array}$ & $\mathbf{0 . 0 0 0 *}$ & $\mathbf{3 9 3 . 5 6}$ & $\mathbf{1 . 5 9}$ & $\mathbf{3 . 2 - 9 . 6}$ & $\mathbf{9 7 . 6 \%}$ \\
\hline $\begin{array}{l}\log R G D P_{t}=\beta_{0}+\beta_{1} R F D I_{t} \\
+\beta_{2} R D I_{t}+\beta_{3} L F_{t}+u_{t}\end{array}$ & $\mathbf{0 . 0 0 0 *}$ & $\mathbf{1 2 1 . 3 3}$ & $\mathbf{0 . 9 3}$ & $\begin{array}{l}\mathbf{5 . 3}- \\
\mathbf{1 0 . 8}\end{array}$ & $\mathbf{9 2 . 2 \%}$ \\
\hline
\end{tabular}

*Significant at 1 percent level

According to the above table, VIF is less than 10 in two models. Further, the adjusted $R^{2}$ is also very high in all models. The probability for the 
estimated ' $F$ ' value also significant in all models. However, according to the results of Durbin - Watson'd' statistics, autocorrelation problem does not exist in Log-Log model. Therefore, Log-Log model is selected to estimate the linkage between FDI and economic growth in Sri Lanka.

\section{Results and Discussion}

Correlation between FDI and economic growth is 0.934 (Probability $=0.0000$ ). Regression results of $\log -\log$ model is presented in following table.

Regression Results of Gross Domestic Production (Log-Log Model)

\begin{tabular}{|l|c|c|c|}
\hline \multicolumn{1}{|c|}{ Variable } & Coefficient & $\mathrm{t}$ Value & $\begin{array}{c}\text { Probability } \\
(\mathrm{p})\end{array}$ \\
\hline$\beta_{0}$ (Intercept ) & -4.202242 & -3.004151 & $0.0054 *$ \\
\hline $\begin{array}{l}\text { Foreign Direct } \\
\text { Investment } \\
\text { (LRFDI(-2)) }\end{array}$ & 0.042051 & 2.080806 & $0.0464 * *$ \\
\hline $\begin{array}{l}\text { Domestic } \\
\text { Investment } \\
\text { (LRDI) }\end{array}$ & 0.517177 & 7.092404 & $0.0000 *$ \\
\hline $\begin{array}{l}\text { Labor Force } \\
\text { (LLF) }\end{array}$ & 1.263927 & 5.252230 & $0.0004 *$ \\
\hline R-Sq(adj)=97\% \\
*Significant at 1\% \\
\hline
\end{tabular}

According to the above results, all the independent variables are highly statistically significant. The estimated coefficient of FDI indicates that, $1 \%$ increase in FDI will increase GDP only by 0.042 . However, it reveals that the actual impact of FDI can be felt after two years of time lag. Time taken for technical transfers and delays on implementing the agreements signed by the foreign investors and time taken on infrastructural development projects might be the reason for delayed impact of FDI.

In general, foreign direct investment has contributed to Sri Lanka economy in several such ways as technology transfer, promoting export, capital inflow among sectors, develop infrastructure facilities, telecommunication network development, expanding port network, reducing balance of payment problem, creating employment opportunities and skillful laborers, and improving transparency in trade policy and flexible labor market in Sri Lanka.

\section{Conclusion}

The key objective of this study is to emphasize the impact of foreign direct investment in the gross domestic production of Sri Lanka. This objective was evaluated by utilizing multiple regression method. For this evaluation, the secondary data from 1978 to 2012 have been used. Several econometrics techniques including Log-Log model have been used to select the best model. Based on this result, it is proved that FDI is highly and positively correlated to determine GDP at 5\% significant level. This study also reveals that the actual impact of FDI can be felt only after a time lag of two years.

\section{References}

Agrawal, P. (2000), Economic Impact of Foreign Direct Investment in South Asia. India: Indra Gandhi Institute of Development Research. http://rru.worldbank.org/Documents/PapersL inks/1111.pdf

Asafu-Adjaye, J. (2000), The effects of foreign direct investment on Indonesian economic growth, 1970-1996. Economic Analysis and Policy.30(1): 49-62

Alam, M.S. (2000), "FDI and Economic Growth of India and Bangladesh: A Comparative study", Indian Journal of Economics, vol. 1xxx, part 1, no. 316, pp. 115. 
Balasubramanyam, V.N., M. Salisu \& D. Sapsford.(1996), Foreign Direct Investment and Economic Growth in EP and IS Countries. The Economic Journal, 106 (Jan): 92-105.

Bashir, A.M., (1999), Foreign Direct Investment and Economic Growth In Some MENA Countries: Theory and Evidence. http://www.luc.edu/orgs/meea/volume1/bcas hir.pdf

Board of Investment of Sri Lanka.(1998), Sri Lanka Investment Policies and Incentives. Colombo: Board of Investment of Sri Lanka

Board of Investment of Sri Lanka. (2012), Statistical Abstract. Colombo: Statistical Unit.

Central Bank of Sri Lanka. (2002), "Foreign Direct Investment in Sri Lanka". News Survey. 23(3): 8-10

Central Bank of Sri Lanka.(1995 - 2012) . Economic and Social Statistics of Sri Lanka, Colombo: Central Bank of Sri Lanka.

Chakraborty, C. \& P. Basu. (2002), Foreign Direct Investment and growth in India: A co integration approach, Routledge. http://www.tandf.co.uk/journals

Chen, C.L. Chang and Y. Zhang, (1995), The Role of FDI in China's post 1978 Economic Development, World Development, 23, No. 4, pp. 691-703.

Chenery, H. B. and A.M. Strout, (1966), Foreign Assistance and Economic Development, American Economic Review, 56, pp. 679-733.

Cortright, J. (2001), New Growth Theory, Technology and Learning. Portland:
Impresa. http://www.eda.gov/ImageCache/ EDAPublic/documents/pdfdocs/1g31r_5f7_5 fcortright_2epdf/v1/1g31r_5f7_5fcortright.pd $\mathrm{f}$

De Mello, L.R. (1997), Foreign Direct Investment in Developing Countries and Growth: A Selective Survey. Journal of Development Studie.34 (1): 1-34.

Hassan, K.M. (2003), FDI, Information Technology and Economic Growth in the MENA Region. University of New Orleans: Department of Economic and Finance.http://www.erf.org.eg/tenthconf/Tra de_Presented/Kabir_Hassan.pdf

Institute of Policy Studies of Sri Lanka. (2000), Foreign Direct Investment and Economic Integration in the SAARC Region, Colombo http://www. saneinetwork.net/pdf/SANEI_ISAARCregio n.PDF

Jansen, K. (1995), The Macroeconomic Effects of Direct Foreign Investment: The Case of Thailand. World Development. 23(2):

193210.http://ideas.repec.org/a/eee/wdevel/v 23y1995i2p193-210.html

Kohpaiboon, A. (2000), Foreign Trade Regime and FDI- Growth Nexus: A Case Study of Thailand. Research School of Pacific and Asian Studies. Australian National University.http://rspas.anu.edu .au/economics/publish/papers/wp2002/wpecon-2002-05.pdf

Moudatsou, A. (2001), Foreign direct investment and Economic Growth Evidence from 14 Europe and Union Countries.www.cs.teiher.gr/school/sdo/ep_lo g_en.html. 
Ram, R. and H.K. Zhang. (2002), Foreign Direct Investment and Economic growth: Evidence from cross-country data for the 1990s. Chicago:University of Chicago.

Rodan, R.P.N.(1961), International Aid for underdeveloped Countries. Review of Economics and Statistics, 43, pp.107-138.

Shaoo, D. \& M. Mathiyazhagan. (2003), Economic Growth in India: Does Foreign Direct Investment Inflow Matter? The Singapore Economic Review. 48(2): 157171.

Sun, H. (1998), Macroeconomic Impact of direct Foreign investment in China: 19791996.UK: Blackwell Publishers Ltd. 